\title{
The Development and Sustainability of the Concept of the State
}

Doi: 10.23918/ilic2021.36

Hoshang Dara Hama Ameen

Lecturer at Soran University, Faculty of Law, Political Science and Management; Kurdistan

Region of Iraq

hoshang.hama@soran.edu.iq

Dr. Saeideh Shariati Najafabadi

Associate Professor at Soran University, Faculty of Law, Political Science and

Management, Kurdistan Region of Iraq

saeideh.shariati@soran.edu.iq

\section{Introduction and Methodology}

Introduction: The present paper is a research studies the concept of the state and examines its development and sustainability. In general, it is about analysing the concept in a way that it could be understood as an abstract concept through the history of political philosophy. It, moreover, will go under discussion in a way that the state's elements would be highlighted in more than one perspective. Here, state has been considered from different perspectives as a multi-dimensional and multi-aspect concept. This is to find the contractions and paradoxes in human thoughts and practices on the states. All of these could led the paper into a conclusion that can prove which the state as a concept is developing its appearances and manifestations, and preserving its essence and its core nature at the same time.

Background of the Study: The concept of the state has always been the focus point to those who study politics; this is to an extent that politics has been defined as the study of state. The fact is that, the state still is what mainly shapes the life of individuals within a society and also the way that the international relations are functioning. This, simply, means that the state still is an undeniable and a functioning actor. Beside this sustainability, the state has been developed in terms of both its conceptual meanings and functional tasks. However, it is still almost what it was, as an abstract concept. Thus, it can be argued that the essence of the modern and contemporary state is almost the same as the ancient and medieval ones. The conceptual and technological developments of human life have re-designed and re-masked the state; however, it could not change its essence. Nowadays, while the four essential elements of state still are there, state has become a multi-aspect phenomenon which also embraces some more moral, legal, political and civic aspects.

The Significance of the Research: The present study aims at analysing why and how the state remains as the same as it was, while almost everything has changed during these millennia. The research tries to rethink, if not redefine, the modern and contemporary understandings of the state as a concept. It discusses the related paradoxes of the concept of the state within philosophy, law and practical politics. In doing so, the research would argue how now statehood can be shaped and to what extent the power and interest of the others are having role in it. Thus, it evaluates the power, as state's main essence. These discussions would highlight the concept of the states in ancient, medieval, modern and contemporary era, as well as in international law and politics too. It is also about finding the real nature of the state, when it was shaped based on natural theories, developed by theocratic ones, then established by the social contract theories.

The Research's Questions: The paper would ask several questions, such as: to what extent the contemporary state could be considered as the extension of modern, medieval and ancient ones? What are developments that the state as a concept has experienced and how it could preserve its main essence and always remains as state itself? How the newly-discovered tools of statehood are being used aiming at achieving the state's oldversion goals? 
The Research's Methodology: To address the above mentioned matters, the study uses qualitative methods of analysis within the framework of political science. It depends on secondary data to analyse related themes from different philosophical, legal and political perspectives. Here, the state, as a multi-dimensional and multi-aspect concept would go under analysis. This will be about deconstructing the concept of the state into its component elements to know what state made of; and then to reconstruct them in a different way to know what the real nature of the state is. In doing so, the methodology has been used in order to guide the paper to where the questions would be answered.

The Research's Structure: The research has been structured in a way that its chapters and section be helpful to conduct the methodology and to answer the questions. In doing so, the paper starts with an inclusive introduction, including methodological matters too. Then it would be followed by a philosophical conceptual framework of the concept of the state, focusing on the concept within different phases of the history of philosophy - ancient, medieval, modern and contemporary. After that, the concept of the state would be analysed from a legal perspective; both local and international law and focusing on population, territory, government and sovereignty or recognition as the four elements of the state. This will be followed by another section focusing on finding the paradoxes of the international law in relation to the state. Finally, the paper would be concluded in a Conclusion, to summarise what the research has resulted.

\section{The Political Philosophy of the Concept of the State}

There are different methods to classify philosophical understandings of a concept. Here, it is believed that depending on different periods of history is the most suitable with regard to the present research. Therefore, the attempt here is to understand the political philosophy of the concept of the state throughout the history of thoughts. To do so, all ancient, medieval, modern and contemporary understands of the state will go under the light.

As it is accepted that the politics is almost about studying the state, then it can be accepted that for the political philosophy the aim is to think about the state too. However, what here is needed to be discussed is general features of the thought within the four mentioned periods of the history of the philosophy. This will be helpful in offering a general overview of what the political philosophy of the concept of the state is about. This is also about explaining the extent of development and sustainability of the concept of the state during the history of political philosophy.

\subsection{Ancient Understandings of the Concept of the State}

Generally, it has been well accepted that Greek is a good example to clarify how the ancient philosophy of the state is about. Besides, the experiences of Roman Empire are good ones at understanding the practical examples of how state had been understood and how it was functioning. Here, all needed is that to discuss the apparent features of this era, focusing on Greek's experiences. Thus, mentioning Aristotle's works and city-state's experiences would be helpful to know how ancient philosophers were thinking about the state.

For the Greek people, state is thought as something natural. It could be mentioned as any creature. It is natural just like how family is. It also can be seen like an organism - just like any other organisms. In shaping this kind of thinking both Aristotle and Plato had role (See: Joffe, 2018). They developed evolutionary and organic theories of the state. The first one, which is linked to Aristotle, briefly is that the state is extension of human nature, or man's natural life. Man is believed as a socio-political animal that forms a family, then a village, and then a state. Thus, the state is the incarnation of man's nature. It is the embodiment of man's needs. Thus, it is natural. It is a natural and gradual process of man's becoming. The aim is people's goodness which cannot be achieved without having a state, because man is a man only when he lives within a state. Therefore, the state can be defined as a form of community which covers all individuals within a specific area who are governed by one, a group or by themselves in a specific kind of political system. 
Consequently, the state is a natural organ. It grows to a degree that can embrace all men and their associations (See: Mijuskovic, 2016).

For Greeks, who lived in city-states and experienced a direct democracy, the state was the highest human form of community. Their political life was characterized by features like the rule of frees and the majority of slaves. Besides, the Romans were about living in a bigger community than a state. They formed an empire, followed an emperor and used power and force. Their political association was bigger, larger, broader, and more complicated. It was depending on both power and force. Thus, for the Romans, the state was the result of their own struggle. It was real, not just a notion.

\subsection{Medieval Understandings of the Concept of the State}

The medieval understandings of the concept of the state are characterized by the deeprooted conflict between the state and the church. That was because of the growth of religious interpretation for the worldly matters, including the rule and governance. This paved the way to rise various theocratic theories of governance (Innes, 2000). Nevertheless, almost all of them were the same: the legitimacy is something divine. Here, the rise of that a different tendency, a synthesis, was not a surprise. Thus it is not only about the church, but the state too - as well as, it was not only about the religious thoughts, but the secular ones too. Nonetheless, the fact was that Christianity, and its institutions, had a major impact on both people's life and thought (See: Møller, 2018).

Here, the concept of the state was lost its Greek flavour. Now, the state is a bout a feudal institution which is functioning for the favour of the church. To guarantee this, the church was limiting the liberties to a degree that all should be in accordance to the church's interpretation of the Bible. Therefore, it can be analysed as the state, in medieval era, was not an independent institution which can cover all other ones, just like what was in Greek thoughts. Besides, the state was looking and even functioning like an institution of the church which was wanted to be ruled by religious leaders. Here, the controversy of state vis-a-vis states was the extension of the dialectic of body vis-a-vis sprit. The church was thinking that the sprit is superior to the body and both should be functioning in accordance with its teachings - the way of thinking that was being rejected by seculars (See: Innes, 2000).

Another characteristic of the medieval eras was that monarchy accepted as the best form of governance. This is because the monarchs were linked their rule to the divine and kings were linked to the God. All of this was at the time that the impact of religion on people's thought was high. Practically, beside the fact that the state was ruled by the emperors and monarchs, and the church was highly effective and competitive to the state, the medieval societies were feudal ones. This shaped the state's economy and had impact on way that the state can be understood. Consequently, the medieval understanding of the state was that people were obeying a dual ruling institution, a combination of both the king and the church at the same time. Thus the state was about to lose its sovereignty and there was a lack of a sovereign authority, as sovereignty was defined as something linked to the divine, but not the people (See: Gierke, 1913).

\subsection{Modern Understandings of the Concept of the State}

Modern philosophers, enlightenment, renaissance and industrial revolution all had role in changing the way of thinking about almost everything and of course about politics and statehood too. For the modern era, the focus point of political philosophy was not based on metaphysical and religious beliefs; it was, and still is, based on believing in man's reason and choice. Thus, the modern era is the era of man's role in his own life. This can be argued that started with Niccolo Machiavelli, who suggested the separation of politics from religion and ethics. Then, it was developed by Thomas Hobbes, how beloved on materialism and suggested that the state is a man-made material. Then, it had been even more developed by John Lock, who suggested that peoples are having right to revolt against tyranny and despotism (See: Bosanquet, 2001). 
The modern characterized bye the social contract theory, in which state is made out of humans' efforts to leave the state of nature. Thus, state is a manmade stuff and is a result of a social contract which held aiming at transferring from the state of nature to a civil condition, or a civil state. Thomas Hobbes (1588-1679), John Locke (1632-1704), and Jean-Jacques Rousseau (1712-1778) as the theorists of the social contract theory has developed the theory in different perspectives and established a modern way of thinking about the states which has never been expired. Here, the term of modern is about transcending both medieval and ancient beliefs towards human nature and destiny. Thus, modernity began with modern ideas and then reached to modern institutions and stuff (See: Bosanquet, 2001).

Modernity is also about the development of different ways of thinking and the appearance of different ideologies, in which they try to offer a modern interpretation for the human phenomena. The most effective ones of these ideas and ideologies could be secularism and rationalism, capitalism and communism, colonialism and imperialism, nationalism and forming nation-states, democracy, human rights and self-determination. All of these notions, beside the industrial and technological developments, were shaped the way that the modern state is functioning (See: Williams, 1998). Nevertheless, modern states are characterised by the rise of different political institutions within the state as a mega institution which embraces all of them. This, of course, were not limited to the local level of the state, but it covers its international dimensions too, as there were the rise of regional and international institution which changed the way that the modern world is functioning (Vargas-Hernández, 2016).

\subsection{Contemporary Understandings of the Concept of the State}

Contemporary era is an extension of the modern one. There are not dramatic changes on the modern philosophical understandings of the concept of the state. However, the changes are mostly related to the practical aspects of the state and society. Generally, the contemporary era has shaped the modern thoughts in a more organised way. For example, the idea of social contract theory has developed to written constitutions, in which the relation between the ruler and people has been designed (See: Bosanquet, 2001). Principally, the state has remained in its modern-Westphalian form; nevertheless, its institutions have been developed in terms of both quantities and qualities (Spruyt, 2002). The contemporary era is about to rise much more institutions and companies with more roles and functions - such as national and international banks, national and international armies or military coalitions, local or multinational companies.

The contemporary understandings of the concept of the states have been shaped based on what the modernity had begun with. This era has not been able to provide a more solid theory than those which have been provided in modern era on different issues, including the state formation and its development. Besides, the revolution of information and communication technology, as a more developed phase of the industrial revolution, has changed the way that the state and other institution are conducting their functions (Williams, 1998). It has bolded or lightened, in a way or another, the roles that different actors had in modern era. In other words, the contemporary era has not innovated much of the new concepts, but has attempted to redesign the modern ones. Nowadays, because of the characteristics of contemporary era, almost everything is experiencing having a 'more' before itself; such as: a more developed and a more globalized (See: Solakoglu, 2016). Thus, these contemporary changes, of course, are in need of contemporary interpretations and understandings.

In the contemporary era, the state still is conducting its basic modern function, but in a contemporary way. It is still the most sovereign master inside its borders and also the main actor in international relations. Nevertheless, a more active and effective role has been given to the non-governmental organisations inside the state and to the non-state actors in international arena. Nowadays, international organisations like the United Nations are 
having much more role in international issues; and regional organisations like the European Union are playing role as a block of shared interests and values. Thus, the world is stepping towards an environment with lots of harmonies and contradictions at the same time. Nonetheless, state has remained as the most desired form of coexistence among peoples. People's struggle to build their own independent state is continuing and nations are awaking to get what they deserve. Consequently, state still is what Aristotle defined as the heights form of human community which is above all communities. Furthermore, people/s around the world are still being organised within the borders of the states. That is mainly because man still is that social and political animal who cannot be separated from a political life of a state.

\section{The Legal Perspective of the Concept of the State}

Here, it is important to have a legal perspective on the concept of the state. This should be done by drawing a legal framework for the concept. That is because the state is not only a political manmade shape, but it also has its own legal criteria, based on what have been called as domestic and international laws. The fact is that the state has to have some legal conditions and follow some more in order to be a functional institute. Generally, it has been accepted that the four elements of the state are population, territory, government and sovereignty or recognition. Here, all of these elements will go under discussion aiming at offering a narration on what state made of and how the nature of these four elements of the state can be changed from time to time (See: Duguit, 1917).

Drawing a legal framework for the concept of the states is a proper method to analyse the concept. In doing so, the state as a concept would be divided into its elements, its parts. Thus, understanding the nature of each element makes the concept of the state clearer and reduces its opacity. This opacity has came form the political nature of the states which it has been widely interchanges with the term of power in both theory and practice. Thus, drawing a legal framework and having a legal perspective on the concept of the state would be helpful in offering a clearer and bigger picture of what state is. Nonetheless, here, the four elements of the state, as they have been widely discussed in the related literature, will be rethought in a different way than the prevalent way in which they are considered in an abstract way (Ibid).

\subsection{Population or Permanent Residents}

The first and the most significant element of the state is population. That is because the state has been made for and of people. Population is a bout a considerable number of people who coexist, having sharing identity/interest, and following a shared destiny (Knight, 1992). While having a big number of people makes state stronger and could be considered as a pillar of power, forming a state is not about number. Besides, it is, to an extent, considered as forming a state for some few hundreds or even thousands of people is not applicable. Thus, there are states around the world with different sizes of population - from thousands to millions and even more. Nevertheless, what is important is having or feeling to have shared identity and/or interest - linked to the past and future. This simply means that they feel that they are different than others and so that their interests are different too. This feeling, which mostly, has been developed to nationalism as an ideology, is about to follow almost the same destiny. The people/s of a state think that what can be good or bad, will be good or bad for almost all the population. That is why they are forming a state for their own goodness.

The social mosaic of the population or permanent residents of a state has always been something different from time to time and from somewhere to somewhere else. It has changed during history, from tribes and nomads to permanent residents, nations and then peoples. Thus, there were/are states which have been formed for only a nation, like solo nation-states, or for more than a nation, like a multiethnic and multinational states. There are examples like a state for a nation, a state for more than a nation; and also there are nations who have more than a state; also there are stateless nations too (Opello \& Rosow, 
1999). Generally, throughout the history, states have been formed for resident populations on a specific territory. However, their socio-political mosaic has been changed and these people have been classified, if not divided, into different groups; such as social classes, ethno-sectarian groups, nations, political parties, and finally independent individuals. The modern states are usually the result of independent and nationalist struggles. They have been formed for ethnic groups and nations to rule themselves and also to represent those peoples within international arena. Nowadays, individualism has developed to an extent which it could be said that the state is made of and for its individuals. Nonetheless, there are considerable efforts to form new states from the existing ones, based on nationalist ideas.

\subsection{Territory}

The permanent residents who are building a state should have land to live on it; thus the territory is the second element of the state. Territory is a clearly defined border in which within it the state will be built (Knight, 1992). While having a large area, fertile soil, good topography, good enough springs and rivers, having all four seasons, locating on the sea and other arrangements of the land are significant to make a strong state; however, it is not a condition to build a state. That is why there are different states with different topographic characteristics - from small to large, from an integrated land to divided islands, and all other types. The developed technology has changed the importance of the land; however, it is still a strategic pillar of power for the state.

Various factors can decide on drawing the border of a state. These could be linked to the domestic power of a state itself and the limit that the international community put on the state. Therefore, while almost all states are having desire to enlarge their border, but this has been limited by military powers, political conventions and the international law. Nevertheless, the strong and powerful states have also changed their way of contesting and occupying other states. The colonialist methods of directly and physically occupying of a state have changed to imperialist methods and cultural and political invasions. Besides, the fact is that almost everywhere on the earth is occupied by states, legally or illegally. Thus, nowhere is out of the geographic and/or political borders of the state.

\subsection{Government}

To build a state, the permanent residents, who live on a clearly defined border, need a capable political organisation in which able to govern the people and protect the borders. This is called a government, another element of the state (See: Kukathas, 2014). It is obvious that there are different types of government; however, as an element of the state, the government's type is not a condition. What is needed is government's ability to rule and this could be thorough any type of government - from a monarch to a democratic one. Nevertheless, nowadays, not legally, but politically, the more democratic governments are more easily recognised and supported by international community. This is because, todays, as the democratic regimes are preponderance (Deutsch, 1986).

During the history, the philosophy of governance has changed. In ancient and medieval era governance was about the rule of an empire or a monarch family in which the institutions were very limited. The way of governance was centralism, backed up by a feudal society (Innes, 2000). Then this has changed towards freer and more democratic societies in which people's rights were much more respected. Thus constitutional monarchies and then democratic systems appeared. Nowadays, democratic governments are prevailing, even if in theory. They enjoy having popular legitimacy, conduct free and fair elections, and respect human rights and so on. However, they are not functioning like each others; but based on the way they conduct, there are different classification of the governments. One of a widely accepted one is to classify them as strong, weak, failed and collapsed governments (See: Barkey \& Parikh, 1991). Here it should be noted that while building a state requires having an enough strong government, the collapse of a government does not means the end of the state too. 


\subsection{Sovereignty / Recognition}

For the permanent residents who live within a border and governed by a government achieving sovereignty is the last condition to get their independence. Thus, sovereignty is the last element of the four elements of the state. The fact is that the state comes into being when it has been recognised by other states. That is because the one feels that they are there only when recognised by others - this is almost the same for the state too. Thus, becoming a member of states' family requires recognition by other member/s (Stirk \& Schuett, 2015). State's are legally recognise those governments which are having supremacy over their people/s, individuals and groups, within their borders and also having independency from external control. However, the interest of the powerful states and international community is the factor that will make the final decision on the issue of recognition. Therefor, the sovereignty will, legally and theoretically, can be achieved when a government recognised by other states to rule a specific people on a specific era, externally; and internally, when it is capable to produce and enforce laws and policies to protect itself, its people and its territories (See: Spruyt, 2002).

While to be recognised only by a recognised state is enough to become a state, being recognised by more states will give the state more legitimacy, power and support. Besides, there are states that have been recognised by only some few other states, while they are formally states, but having lot of obstacles in functioning within the international community. On the other hand, there are states that have been widely recognised by the members of the international community, but they lack internal legitimacy and popular support. Therefore, while sovereignty is an abstract concept, its nature is different from time to time, and from a state to another - and that is based on the way that the state is functioning and the way that the state is being analysed. This made the scholars to classify states into different groups; such as quasi states, state-to-be, de facto states and more. Nowadays, the meanings and application of the concept of the sovereignty have been changed. Governments are less depend on traditional methods and charismatic characters of legitimacy, but mostly depend on rational-legal factors of achieving legitimacy as a way towards being a recognised sovereign state. Besides, practically, the international law, the interest of international community and international values, such as human rights and democracy, are considered as conditions to achieve recognition internationally. Furthermore, the meanings of the concept of sovereignty have been changed due to the human and technological developments that the era witnessed (See: Williams, 1998). An example is the absoluteness character of the concept of sovereignty which has been limited both internally and externally. That is mainly because of the revolution of information and communication technology and also because of the practices of international relations which are mostly in contracts to the rhetoric of the states. Nowadays, sovereignty is less about the state's monopoly of the use of violence, in a Weberian concept (See: Anter, 2014). It is, however, about drawing a legal framework for state's use of force both internally and externally to be limited by the international law and the moral principles of international community (See: Barkin \& Cronin, 1994).

\section{The Politics and Paradoxes of the International Law}

The practice and politics of the state is different than the state itself as an abstract concept in philosophy or law. Thus, understanding state as it is requires having a look at it as something in practice. In doing so, the paradoxes of the international relations will be much more understandable. In this section the concept of the state would be considered as a result of what happening in de facto, more than what that has been considered as something de jure. Moreover, the discussion on the would continue to a degree that state be considered as a result of the power and interest of the others more than the power and will of a permanent residents on a specific land who are organised by a government and planning to be sovereign. In doing so, the paradoxes of the right of self-domination and the principle of territorial integrity would be discussed. While these two are widely accepted 
and respected in international community, they are in contrast to each other in a way that almost all newly built states based on the right of self-determination would endanger the principle of the territorial integrity of a state in a way or another.

The fact is that the politics of international system and the paradoxes within the international law are shaping the way that the state family is functioning (Stirk \& Schuett 2015). The shared interest of powerful states, intended and different interpreting of the international law and neglecting the international moral norms, all make the process of building a new state much more complicated. That is why in the last two decades only five states have announced their independence; this is in a time that there are dozens of independency struggles around the world. This made the matter of statelessness of nations and peoples around the world stay unsolved. Becoming a sovereign and internationally recognised state has become more complex than the last periods of history; for instance, the periods of after the World War I and the World War II (See: Barkin \& Cronin, 1994). This indicates that the de facto international politics and the existing states are about to be even more conservative in changing the way that the world has been mapped.

\subsection{State as Power}

The fact is that the state is nothing but the embodiment of power. Furthermore, it is a tool to exercise power. Thus, what produces a state and what a state produces is power. In different periods of history, power had played the main role in forming, dividing, dissolving and demising states. Going back to the ancient era, when the force theory of forming the state is much more applicable, and then to the post-colonial era, when the liberation movements resulted in independencies, power has always been the main factor that decided on both birth and death of states (See: Jessop, 2015). In modern and contemporary eras, newly-built states can be analysed as a result of reincarnation of power in different bodies (See: Sabine, 1920).

Power, nowadays, is not an abstract concept to be only in the mind and hand of a nation, but a world system too. This means that newly-built states can be considered as the result of the whims of the international powers in interpreting the international law in a way that could be resulted in new state born. Power, nowadays, is prevailing over the law, just like how de facto does on de jure. Thus, internally the power of a nation and international the power of the system determines the performances of the state and guarantees its maintenance (lbid).

\subsection{The Right of Self-determination vs. the Principle of the Territorial integrity}

Power and politics has caused lots of paradoxes within the international laws and principles. For instance, self-determination and territorial integrity have been added to the international law as respected principles. While these two are in contract to each other, they have been used, even exploited, to guarantee remaining the balance of power within the world system. Thus, while the international law, the United Nations charter, and the international norms, Woodrow Wilson's fourteen points, support the right of selfdetermination for stateless nations, it also supports the territorial integrity of the existing states too. This is a clear paradox which paves the way to powerful states to exploit the international norms, laws and principles. Great powers are interpreting these principles for their own interest and their interest is what drives the international relations - in which it definitely will be having impact on the state in its different levels of local, regional and global performances. There are lots of liberation movements, who seek their right of selfdetermination, which have been accused as they are separatists, who work against the country's territorial integrity. Besides, there are also some more national and popular movements that have been supported by international system to be able to get their statehood; as well as there are supports of the system for lots of existing states to defend and protect its territorial integrity (See: Kantorowicz, 1932). 
Consequently, the world system and great powers, based on their own interest, would decide when and where the right of self-determination or the principle of territorial integrity would be functioned. The criteria to do so, as Zacher (2001) suggests, is security issues. The use of security also could be to create kind of harmony within all of those contradiction of the contemporary values and interests. Zacher approaches the issue through a security lens and suggests that "while self-determination for ethnic groups is at times viewed sympathetically by liberals, it is 'trumped' by their recognition that the logical outcome of allowing self-determination for every national group would be continual warfare" (p239). He adds that "self-determination has had to be compromised in the pursuit of physical security, which is itself necessary for individuals' realization of liberty. Hence, democratic states' fear of major war and their respect for self-determination by juridical states are inextricably interrelated in their support for the territorial integrity norm" (p239).

\subsection{Successful, Failed and Planned Attempts of Statehood}

The world map is always changing. However, after the Cold War and the collapse of the Soviet Union, the changes have been very slowed down. That is, partly, because lots of nations could build their won state and get their own independency. Besides, the world politics has changed to a direction which its focus in on issues other than statehood. The more globalized world and the European Union experience, in which it unburdened the hardness of the borders, had also impacted the way that states, nations and even individuals classify their priority (See: Solakoglu, 2016). Then later, other matters such as the increase of insecurity and the number of terror attacks around the world, and then the global pandemic of Covid-19, all had impact on diverting the proposed projects of statehood and also slowing down the changes that the world map could be seen.

Regarding the statehood attempts, within the last two decades, there are a few successful and a few failed of apparent projects of statehood, and a lot of abortive struggles of the existing attempts of statehood still are there. The newest independent states, in the third millennium, are East Timor (2002), Montenegro (2006), Serbia (2006), Kosovo (2008) and South Sudan (2011). Besides, the most apparent failed attempts of becoming independent, based on independent referendums which held, are Scotland in the United Kingdom (2014), Kurdistan of Iraq (2017) and Catalonia in Spain (2017). There are also more scheduled independence referendums to be held in near future; such as: New Caledonia from France (December, 2021) and Chuuk from Micronesia (March, 2022). All of these successful, failed and planned attempts mean that state is still the most preferable organisation for human community; and it also means that statehood still is the most undeniable dream of millions of people around the world.

\subsection{Becoming a Sovereign State}

Nowadays, just like the periods before, becoming a sovereign state requires the four elements of permanent residents, territory, political authority and recognition. However, it does not necessarily means that all entities that have these four elements will definitely become a sovereign state. That is because, beside the legal conditions for forming a state, there are also political conditions which are, indeed, more complex and ambiguous, and less achievable at the same time, than the legal criteria. Nevertheless, there were/are successful attempts of nations in becoming sovereign states, and forming a new independent state is not impossible. But what makes it difficult and harder is that becoming a sovereign state requires overcoming lots of obstacles, both locally and internationally (Vidmar, 2015).

Locally, aside from having the four elements, the nature and condition of those elements are playing a significant role in stepping towards independency and statehood. This means that, for instance, a large number of people in a prosperous society, on a rich and fertile land, well-governed by a civil and democratic government, which enjoy having legality and popular legitimacy, is having more chance in becoming a sovereign state. Thus, cultural values of people, potential economic factors, respecting shared human values, and of 
course security and stability, all are having impact on easing forming a new state. Besides, what is related to it on its international level is that what shapes moderns states is not only the four elements of the state and the right of self-determination (See: Spruyt, 2002). That is because usually the rhetoric would be faced by the practice, the rights self-determination by the principle of territorial integrity, the law and legality by power and interest and so on. Thus, the state, in its international level, would be born only if the new sovereign state is parallel with the interests of great powers and the global politics of the international system (See: Barkey \& Parikh, 1991).

\section{Conclusion or State's Development and Sustainability}

Based on what have been discussed here, it can be argued that, during the history, the understandings of the concept of the state have been changed dramatically. This could be easily found within different phases of human development both ideally and materially. These changes have been impacted by the time, place and conditions that humanity has go through. As, in previous sections, it has been argued the concept of the state has changed its meanings within different majors of political philosophy, legal perspectives and political understandings (See: Vargas-Hernández, 2016). Nowadays, state can be understood as a legal framework for man's life, in terms of all of their socio-cultural and political aspects of life. It is something made by and for individuals in which formed as a result of the necessity of the society to grow. Therefore, the concept of the state, in a way or other, has been developed from a form of human community based on force and/or divine theories to one based on social contract theories (See: Bosanquet, 2001).

Todays, states are understood, formed and ruled in a different method than those in previous periods of time. In contrary to the ancient and medieval era, the modern and contemporary states are mostly open but not closed, democratic but not tyranny, and federal but not central. Furthermore, these changes are not only about the different periods of human history, but about the conditions that humans think in it. Thus, the development of the understandings of the concept of the state is something undeniable, but these developments would never cause to the change of the core understandings of the state itself. This means that there has always been something within the concept of the state that could bear all changed during the history. This could be called as the sustainability of the state.

Here, the term of sustainability of the concept of the state has been used to clarify another core character of the concept. It is abut that, while the state, as a concept, has been changed from time to time, from here to there and in a condition to another, something has always remained as essential characteristics of the state, as the state per se. In terms of the state's sustainability, the four element of the state are a goof example. No state can be formed if there would be lack of one or more of the four elements of the state. Thus, these four elements of the state could represent the physical sustainability of the concept of the state. Besides, these four elements all are integrated aiming at exercising the power itself. Thus, the state has always been something to embody, produce and exercise power; and of course the used methods in doing so have been different. This also has always been under the impact on the power of the others too.

One of the permanent functions of the state has always been making the balance between the power and interest of the state itself and the others. Thus, it can be concluded that during these millennia, what has been changed is the interpretation of the state, but not the state itself. Furthermore, the state-related theories are about offering different views on why and how state has been born and developed. The fact is that, the state has always been the state per se, as an abstract concept, and what has been changed is interpretations and understandings of the state which are being framed within different theories and concepts of political science and philosophy. Consequently, in can be concluded that the concept of the states is having characteristics of both development and sustainability. What has been developed is mostly about state's performance, and what is 
sustainable is mostly about state's essence and its functions both inside its borders and within international community.

\section{References:}

- Anter, A. (2014) Max Weber's Theory of the Modern State: Origins, structure and Significance. Palgrave Macmillan.

- Barkey, K., \& Parikh, S. (1991). Comparative perspectives on the state. Annual Review of Sociology, 17(1), 523-549.

- Barkin, J. S., \& Cronin, B. (1994). The state and the nation: changing norms and the rules of sovereignty in international relations. International organization, 48(1), 107-130.

- Bosanquet, B. (1925). The philosophical theory of the state (Vol. 143). Macmillan.

- Deutsch, K. W. (1986). State Functions and the Future of the State. International Political Science Review, 7(2), 209-222.

- Duguit, L. (1917). The law and the state. Harvard Law Review, 31(1), 1-185.

- Gierke, O. (1913). Political theories of the Middle Age. Cambridge University Press.

- Innes, M. (2000). State and Society in the Early Middle Ages: The Middle Rhine Valley, 400-1000 (Vol. 47). Cambridge University Press.

- Jessop, B. (2015). The State: Past, Present, Future. Cambridge: Polity.

- Joffe, A. H. (2018). Defining the State. Enemies and Friends of the State: Ancient Prophecy in Context, 3-23.

- Kantorowicz, H. (1932). The concept of the state. Economica, (35), 1-21.

- Knight, D. B. (1992). Statehood: A politico-geographic and legal perspective. GeoJournal, 28(3), 311-318.

- Kukathas, C. (2014). A Definition of the State. U. Queensland LJ, 33, 357.

- Mijuskovic, O. Z. (2016). Aristotle s concept of the state. SOCRATES, 4(4), 13-20.

- Møller, J. (2018). Medieval roots of the modern state: The conditional effects of geopolitical pressure on early Modern state building. Social Science History, 42(2), 295316.

- Opello, W. C., \& Rosow, S. J. (1999). The nation-state and global order: A historical introduction to contemporary politics (No. 320.1 O6.). Boulder ${ }^{\wedge}$ eCO CO: Lynne Rienner.

- Sabine, G. H. (1920). The concept of the state as power. The Philosophical Review, 29(4), 301-318.

- Solakoglu, O. (2016). Three different perspectives on the role of the nation-state in today's globalized world. European Scientific Journal, 1-8.

- Spruyt, H. (2002). The origins, development, and possible decline of the modern state. Annual review of political science, 5(1), 127-149.

- Stirk, P. M., \& Schuett, R. (2015). The Concept of the State in International Relations. Edinburgh University Press Ltd.

- Vargas-Hernández, J. G. (2016). The question of changing the concept, role and functions of state. Journal of Humanities, Culture and Social Sciences, 1(02), 7-33.

- Vidmar, J. (2015). The Concept of the State and its Right of Existence. Cambridge International Law Journal, 4(3), 547-565. 
- Williams, B. (1998). The Sovereign State in the 21st Century: Some Implications of Economic Globalization and New Technologies for Political Organization. Senior Thesis Projects, 1993-2002. https://trace.tennessee.edu/utk interstp2/34

- Zacher, M. W. (2001). The territorial integrity norm: International boundaries and the use of force. International Organization, 55(2), 215-250.

\section{Abstract}

The concept of the state has always been the focus point to those who study politics; this is to an extent that politics has been defined as the study of state. The fact is that, the state still is what mainly shapes the life of individuals within a society and also the way that the international relations are functioning. This, simply, means that the state still is an undeniable and a functioning actor. Beside this sustainability, the state has been developed in terms of both its conceptual meanings and functional tasks. However, it is still almost what it was, as an abstract concept. The present paper studies the concept of the state and examines its development and sustainability. It is about analysing the concept in a way that could be understood as an abstract concept through the history of political philosophy. It, moreover, discusses the state's elements in more than a perspective as a multi-dimensional and multi-aspect concept. This is to find the contractions and paradoxes in thoughts and practices on the states. The main argument is that the state as a concept is developing its appearances and manifestations, and preserving its essence and its core nature at the same time. The paper would ask several questions, such as: to what extent the contemporary state could be considered as the extension of modern, medieval and ancient ones? What are developments that the state as a concept has experienced and how it could preserve its main essence and always remains as state itself? To address these questions, the study uses qualitative methods of analysis within the framework of political science. It depends on secondary data to analyse related themes from different philosophical, legal and political perspectives. This will be about deconstructing the concept of the state into its component elements to know what state made of; and then to reconstruct them in a different way to know what the real nature of the state is. The research has been structured in a way that its chapters and section be helpful to conduct the methodology and to answer the questions. In doing so, the paper would have a philosophical conceptual framework of the concept of the state. It also analyses the concept from a legal and political perspectives. These all are about analysing the development and sustainability of the concept of the state.

Keywords: State; Power; Sovereignty; Self-determination; Territorial Integrity. 